\title{
PENINGKATAN KEMAMPUAN LITERASI MATEMATIKA DAN KARAKTER MANDIRI SISWA MELALUI PEMBELAJARAN KUMIMA BERBANTUAN SCHOOLOGY PADA MATERI TRANSFORMASI GEOMETRI
}

\author{
Siti Sriyatun \\ SMAN 1 Rembang, Kab. Purbalingga, Jawa Tengah \\ sitriya@yahoo.co.id
}

\begin{abstract}
Abstrak
Penelitian tindakan kelas ini adalah bertujuan untuk meningkatkan literasi matematika dan karakter mandiri siswa melalui pembelajaran kumima berbantuan schoology pada materi transformasi geometri. Teknik pengumpulan data dilakukan dengan tes dan non-tes. Rata-rata kemampuan literasi matematika pada kondisi awal, siklus 1, dan 2 masing-masing 58,48 dengan ketuntasan 19\%, 71,71 dengan ketuntasan 23\%, dan 79,23 dengan ketuntasan 71\%. Karakter mandiri siswa pada kondisi awal, siklus 1, dan 2 masing-masing mencapai 66\%, 70\%, dan 77\%. Disimpulkan bahwa melalui pembelajaran kumima berbantuan schoology dapat meningkatkan kemampuan literasi matematika dan karakter mandiri siswa pada materi transformasi geometri bagi siswa kelas XI IPS 2 SMA Negeri 1 Rembang tahun pelajaran 2016/2017.
\end{abstract}

Kata kunci: Literasi matematika, mandiri, pembelajaran kumima, schoology.

\section{Pendahuluan}

Kemendikbud mengembangkan Kurikulum 2013 berdasarkan faktor internal dan eksternal. Faktor internal antara lain terkait pemenuhan delapan standar nasional pendidikan dan perkembangan penduduk dilihat dari usia produktif yang mendominasi. Faktor eksternal terkait dengan arus globalisasi dan berbagai isu yang berhubungan dengan masalah lingkungan hidup, kemajuan teknologi dan informasi, kebangkitan industri kreatif dan budaya, dan perkembangan pendidikan di tingkat internasional. Perkembangan pendidikan di tingkat internasional dapat dilihat dari keikutsertaan Indonesia pada salah satu studi internasional yaitu PISA (Programme for International Student Assessment). Laporan studi PISA tahun 2015, menempatkan Indonesia berada di rangking 63 dari 70 negara dengan skor 386 dan rata-rata skor internasional 490 untuk literasi matematika (OECD, 2016). Menurut Murtiyasa (2015), studi PISA intinya terletak pada kekuatan penalaran matematika siswa serta kemampuan menerapkannya dalam kehidupan sehari-hari. Kata literasi matematika masih asing bagi para siswa dan guru di Indonesia. Pulungan (2014) dalam penelitiannya menganalisis bahwa guru tidak mengetahui kompetensi literasi matematika, sehingga belum ada penilaian literasi matematika dalam proses pembelajaran.

SMA Negeri 1 Rembang sudah melaksanakan Kurikulum 2013 sejak tahun 2013. Analisis pada soal ulangan akhir semester ganjil tahun pelajaran 2016/2017 banyak siswa kelas XI IPS yang tidak mengerjakan soal yang berkaitan dengan literasi matematika. Menurut Wardono dan Kurniasih (2015), salah satu upaya yang dapat dilakukan oleh guru untuk meningkatkan kemampuan literasi matematika adalah melakukan inovasi pembelajaran. Salah satu inovasi pembelajaran yang digunakan adalah penggabungan pembelajaran kuantum dan metode mind mapping yang disingkat Kumima dengan berbantuan schoology.

Pembelajaran kuantum berakar dari upaya Lozanov, seorang pendidik yang berkebangasaan Bulgaria yang bereksperimen dengan apa yang disebut sebagai suggestology atau suggestopedia (DePorter dan Hernacki, 2009). Prinsipnya adalah sugesti dapat mempengaruhi hasil belajar dan setiap detail apapun memberikan sugesti positif ataupun negatif. Beberapa teknik dapat digunakan untuk memberikan sugesti positif yaitu mendudukkan 
siswa secara nyaman, memasang musik latar di dalam kelas, meningkatkan partisipasi individu, menggunakan media pembelajaran untuk memberikan kesan besar, dan menyediakan guru-guru yang terlatih.

Strategi pengembangan penerapan pembelajaran kuantum dikenal dengan istilah TANDUR (Tumbuhkan, Alami, Namai, Demontrasikan, Ulangi, Rayakan). Tumbuhkan, dengan memberikan apersepsi yang cukup sehingga sejak awal kegiatan siswa telah termotivasi untuk belajar dan memahami apa manfaatnya belajar; Alami, dengan memberikan pengalaman yang nyata kepada setiap siswa untuk mencoba; Namai, dengan menyediakan kata kunci, konsep model rumus, strategi dan metode lainnya; Demontrasikan, dengan menyediakan kesempatan kepada siswa untuk menunjukkan kemampuannya; Ulangi, dengan memberikan kesempatan setiap siswa untuk mengulangi apa yang telah dipelajarinya, sehingga setiap siswa merasakan langsung dimana kesulitan akhirnya datang keberhasilan; dan Rayakan, sebagai respons pengakuan yang proporsional.

Metode mind-mapping adalah metode yang dapat digunakan untuk memvisualisasikan struktur pengetahuan (Adodo, 2013), dinyatakan dalam mind map. Pembuatan gagasan dalam mind map akan melatih siswa untuk memiliki kemampuan orisinal serta pengembangan dari setiap gagasan yang menumbuhkan kemampuan elaborasi yang membangun sesuatu dari ide-ide lainnya. Setelah itu siswa menyajikan bentuk mind map yang unik dan penuh dengan makna itu di depan kelas untuk melatih siswa memahami mind map yang dibuat dia sendiri dan berlatih untuk mengungkapkan gagasan-gagasannya secara lancar di depan kelas.

Untuk membuat mind map, digunakan bolpoint berwarna dan kertas secara melebar atau horizontal sehingga mendapatkan tempat lebih banyak. Langkah-langkah membuat mind map adalah menulis gagasan utama di tengahtengah kertas dan dilingkupi dengan lingkaran, persegi, atau bentuk lain; menambahkan sebuah cabang yang ke luar dari pusat untuk setiap poin atau gagasan utama dan digunakan warna yang berbeda untuk tiap-tiap cabang; menulis kata kunci atau frase pada tiap-tiap cabang yang dikembangkannya untuk lebih detail yang merupakan inti sebuah gagasan dan memicu ingatan dan digunakan singkatan untuk memudahkan mengingat serta menggunakan simbol-simbol. Hal ini sesuai dengan penelitian oleh Faelasofi, Arnidha, dan Istiani (2015) yang menyatakan bahwa dengan mind mapping siswa mudah mendapatkan ide dan menjadi lebih kreatif dalam mengungkapkan pengetahuan atau pendapat.

Penggabungan tahap pembelajaran kuantum dan metode mind mapping dapat diringkas menjadi 8 tahap pembelajaran. Tahap pembelajaran tersebut adalah menumbuhkan, mengalami, berkelompok, menamai, mendemonstrasikan, mengulangi, penugasan, dan rayakan. Dengan demikian dalam pembelajarn kumima ada 8 tahap pembelajaran. Kegiatan pembelajaran kumima dapat dilihat pada Tabel 1 berikut.

Tabel 1. Kegiatan Pembelajaran Kumima

\begin{tabular}{|c|c|c|}
\hline $\begin{array}{c}\text { Tahap } \\
\text { Pembelajaran } \\
\end{array}$ & Kegiatan Guru & Kegiatan Siswa \\
\hline Menumbuhkan & $\begin{array}{l}\text { Guru menyampaikan semua } \\
\text { tujuan pembelajaran dan } \\
\text { memotivasi siswa. }\end{array}$ & $\begin{array}{l}\text { Siswa mendengarkan pendahuluan } \\
\text { dari guru tentang materi yang akan } \\
\text { dipelajari }\end{array}$ \\
\hline Mengalami & $\begin{array}{l}\text { Guru meminta siswa untuk } \\
\text { menyampaikan pengalamannya } \\
\text { tentang materi yang akan } \\
\text { dipelajari }\end{array}$ & $\begin{array}{l}\text { Siswa mencoba mengingat } \\
\text { pengalaman yang berhubungan } \\
\text { dengan materi yang akan dipelajari }\end{array}$ \\
\hline
\end{tabular}




\begin{tabular}{|c|c|c|}
\hline $\begin{array}{c}\text { Tahap } \\
\text { Pembelajaran }\end{array}$ & Kegiatan Guru & Kegiatan Siswa \\
\hline Berkelompok & $\begin{array}{l}\text { Mengorganisasikan siswa ke } \\
\text { dalam kelompok-kelompok } \\
\text { belajar. }\end{array}$ & $\begin{array}{l}\text { Siswa belajar dan bekerja } \\
\text { berdasarkan instruksi dalam LKS } \\
\text { dalam kelompok }\end{array}$ \\
\hline Menamai & $\begin{array}{l}\text { Guru mengamati dan memotivasi } \\
\text { siswa berinteraksi dengan } \\
\text { kelompok. } \\
\text { Guru membimbing kelompok } \\
\text { siswa untuk menarik kesimpulan. }\end{array}$ & $\begin{array}{l}\text { Siswa membuat mind map } \\
\text { Siswa bersama kelompok } \\
\text { menyimpulkan hasil kegiatan } \\
\text { pembelajaran. }\end{array}$ \\
\hline Mendemontrasikan & $\begin{array}{l}\text { Guru mengamati dan } \\
\text { membimbing siswa dalam } \\
\text { mempresentasikan hasil kerja } \\
\text { kelompok }\end{array}$ & $\begin{array}{l}\text { Siswa memaparkan hasil kegiatan } \\
\text { pembelajaran kelompoknya dan } \\
\text { kelompok lain sebagai evaluator. }\end{array}$ \\
\hline Mengulangi & Guru memberi kuis langsung & $\begin{array}{l}\text { Siswa mengerjakan soal kuis yang } \\
\text { diberikan guru }\end{array}$ \\
\hline Penugasan & $\begin{array}{l}\text { Guru memberi tahu ada tugas } \\
\text { yang dikerjakan secara individu }\end{array}$ & $\begin{array}{l}\text { Siswa mendengarkan pemberitahuan } \\
\text { guru }\end{array}$ \\
\hline Rayakan & $\begin{array}{l}\text { Memberikan penghargaan } \\
\text { kelompok berdasarkan skor } \\
\text { masing-masing kelompok }\end{array}$ & $\begin{array}{l}\text { Siswa secara bersama-sama } \\
\text { merayakan hasil belajar yang telah } \\
\text { dicapai. }\end{array}$ \\
\hline
\end{tabular}

Penugasan dapat dilakukan dengan berbasis TIK. Salah satunya dengan menggunakan Learning Management System (LMS) schoology. Schoology adalah sebuah situs yang menggabungkan fitur jejaring sosial dan LMS. Melalui schoology, bisa berinteraksi sosial sekaligus belajar. Schoology mirip seperti edmodo, dengan kelebihannya pada beberapa fitur. Adapun fitur-fitur yang dimiliki oleh schoology adalah courses (kursus), yaitu fasilitas untuk membuat kelas mata pelajaran, misalnya mata pelajaran matematika, groups (kelompok) yaitu fasilitas untuk membuat kelompok, dan resources (sumber belajar). Tampilan fitur schoology dapat dilihat pada Gambar 1.

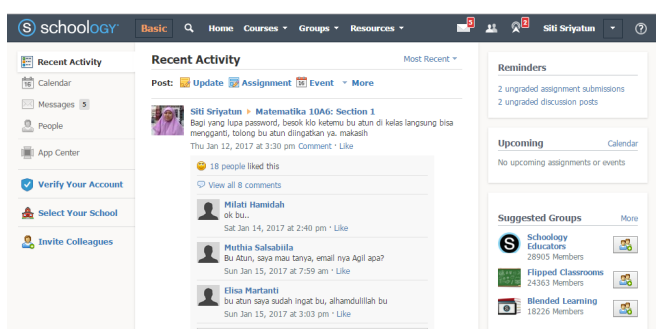

Gambar 1 Tampilan Schoology
Pada menu course bisa membuat kuis yang jenisnya banyak, yaitu pilihan ganda, benar salah, menjodohkan, dan isian singkat. Pembuatan soal di schoology ini dilengkapi dengan symbol, equation, dan latex. Jadi, semua jenis soal yang mengandung gambar, simbol, dan equation dapat ditulis di schoology. Selain itu, untuk memasukkan anggota atau siswa yang ikut di kelas yang diampu cukup memberikan kode kepada siswa yang diajar. Kelebihan dari schoology menurut Amiroh (2013) yaitu pada schoology tersedia fasilitas attendance atau absensi, yang digunakan untuk mengecek kehadiran siswa, serta fasilitas analytic untuk melihat semua aktivitas siswa pada setiap course, assignment, discussion, dan aktivitas lain yang telah disiapkan untuk siswa. Tugas sebagai umpan balik dalam pembelajaran dapat diberikan dengan proses di luar tatap muka melalui schoology. Sarana yang digunakan dapat melalui handphone android. Sekarang semua siswa sudah membawa handphone android. Selain itu, jika waktu dalam pembelajaran tatap muka masih 
kurang dapat dipenuhi dengan proses di luar tatap muka melalui schoology ini. Fitur yang digunakan adalah diskusi. Guru memberikan permasalahan dan siswa mengajukan pendapat. Siswa lain bias menyampaikan gagasan atau memberi komentar dari pendapat temannya. Akhirnya guru menyimpulkan penyelesaian dari permasalahan tersebut. Ini berarti pembelajaran sudah memanfaatkan sarana yang sudah ada pada siswa. Siswa menjadi terlatih bekerja secara mandiri dengan berbantuan internet. Dengan demikian tujuan penelitian ini adalah untuk meningkatkan literasi matematika dan karakter mandiri siswa melalui pembelajaran kumima berbantuan schoology pada materi transformasi geometri.

\section{Metode Penelitian}

Jenis penelitian ini adalah penelitian tindakan kelas. Penelitian dilaksanakan di SMA Negeri 1 Rembang kelas XI IPS 2 tahun pelajaran 2016/2017 dengan 31 siswa yang terdiri atas 12 laki-laki dan 19 perempuan. Penelitian dilakukan dengan 2 siklus, masing-masing siklus 2 pertemuan. Siklus 1 dilaksanakan pada tanggal 10 dan 18 Mei 2017. Siklus 2 dilakukan pada tanggal 20 Mei 2017 dan 23 Mei 2017.

Variabel yang diungkap dalam penelitian ini ada dua, yaitu kemampuan literasi matematika pada materi transformasi geometri dan karakter mandiri siswa. Subyek dalam penelitian ini adalah pembelajaran kumima berbantuan schoology. Sumber data kemampuan literasi matematika berasal siswa kelas XI IPS 2 dengan data dari kegiatan tes pada kondisi awal, siklus 1 dan siklus 2. Sumber data tentang karakter mandiri siswa berasal dari siswa kelas XI IPS 2 dengan data kualitatif (non tes) yang berasal dari hasil kuesioner dan data dari schoology. Semua data dianalisis menggunakan teknik deskriptif komparatif yang dilanjutkan refleksi. Deskriptif komparatif yaitu membandingkan secara deskripsi data kondisi awal dengan data siklus 1 , membandingkan data siklus 1 dengan data siklus 2 dan membandingkan data kondisi awal dengan data siklus 2. Keberhasilan penelitian diukur adanya peningkatan ratarata kemampuan literasi matematika baik secara individual maupun secara klasikal.
Keberhasilan individual ditentukan dengan banyaknya siswa yang tuntas yaitu siswa yang memperoleh nilai lebih dari atau sama dengan 77 ada kenaikan 10\%, sedangkan keberhasilan klasikal adalah rata-rata hasil belajar naik $10 \%$. Peningkatan karakter mandiri siswa ditentukan dengan persentase naik 10\% secara klasikal.

\section{Hasil Penelitian dan Pembahasan}

\section{Hasil Penelitian}

Data kondisi awal hasil belajar kelas XI IPS 2 diperoleh dari data ulangan harian sebelum penelitian dilaksanakan dengan materi persamaan lingkaran. Siswa yang tuntas hanya ada 6 atau baru mencapai 19\% dengan ratarata hasil belajar 58,48. Karakter mandiri siswa diperoleh dari data sebelum penelitian dilaksanakan yaitu data kuesioner pembelajaran sebelumnya. Data karakter mandiri siswa diambil dari 6 indikator dalam 48 pernyataan. Rekap data dapat dilihat pada Tabel 2 berikut.

Tabel 2. Rekapitulasi Karakter Mandiri Kondisi Awal

\begin{tabular}{lll}
\hline No & \multicolumn{1}{c}{ Indikator } & Persentase \\
\hline 1 & $\begin{array}{l}\text { ketidaktergantungan } \\
\text { terhadap orang lain }\end{array}$ & $64 \%$ \\
\hline 2 & $\begin{array}{l}\text { memiliki kepercayaan } \\
\text { diri }\end{array}$ & $67 \%$ \\
\hline 3 & berperilaku disiplin & $67 \%$ \\
\hline 4 & $\begin{array}{l}\text { memiliki rasa tanggung- } \\
\text { jawab; }\end{array}$ & $62 \%$ \\
\hline 5 & $\begin{array}{l}\text { berperilaku berdasarkan } \\
\text { inisiatif sendiri }\end{array}$ & $67 \%$ \\
\hline 6 & melakukan kontrol diri & $69 \%$ \\
\hline \multicolumn{2}{l}{ Rata-rata } & $66 \%$ \\
\hline
\end{tabular}

Tahap perencanaan pada siklus 1, peneliti mempersiapkan instrumen yang terdiri dari perangkat pembelajaran dan instrumen pengumpul data. Perangkat pembelajaran terdiri dari silabus, bahan ajar, RPP untuk dua pertemuan, dan LKS untuk satu pertemuan. Pengumpul data terdiri dari soal untuk tugas dan diskusi yang diupload di schoology, kisikisi soal tes 1 , tes 1 (4 soal yang bervariasi), pedoman penskoran serta rubrik, dan lembar kuesioner karakter mandiri. Pada tahap ini 
peneliti juga mengadakan pertemuan untuk menjelaskan schoology dan sign up.

Pelaksanaan tindakan pada siklus I terdiri dari 2 pertemuan yaitu pertemuan 1 dan pertemuan 2 . Kegiatan pendahuluan pada pertemuan 1 adalah mengucapkan salam, mengecek kehadiran siswa, mereview pembelajaran sebelumnya, meminta siswa untuk menyanyi sebuah lagu, dan menyampaikan kompetensi dasar dan tujuan pembelajaran dengan materi translasi dan refleksi. Kegiatan inti adalah mengingatkan kembali tentang baris berbaris (menumbuhkan), meminta dua siswa maju sebagai pelaku dan pemberi komando dalam baris berbaris (mengalami), mempersilakan siswa untuk bertanya, dan menanggapi pertanyaan. Setelah kegiatan baris-berbaris selesai, peneliti meminta salah satu siswa maju untuk praktik bercermin. Selanjutnya peneliti membagi kelas menjadi kelompok yang beranggotakan 3-4 siswa untuk membahas LKS (berkelompok). Masing-masing kelompok membuat mind map (menamai). Kegiatan selanjutnya peneliti meminta kelompok untuk maju presentasi hasil diskusi sesuai hasil undian dengan menggunakan mind map yang ditayangkan melalui LCD (mendemonstrasikan). Foto kegiatan ini dapat dilihat pada Gambar 2 berikut.

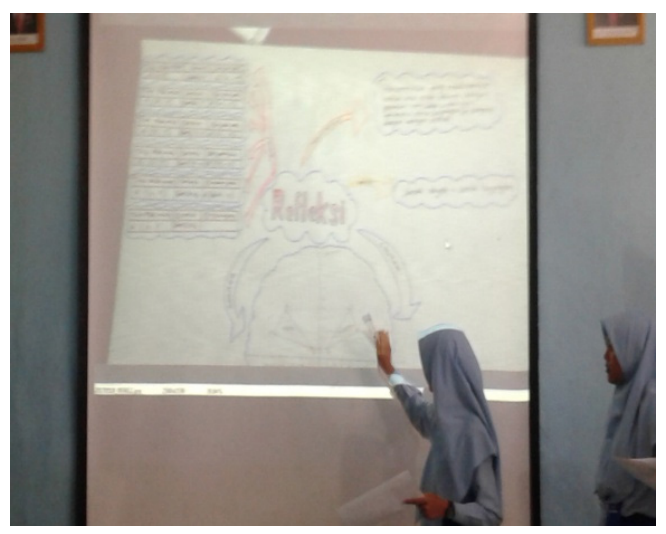

Gambar 2. Kegiatan Mendemonstrasikan
Selanjutnya peneliti memberi kuis (mengulangi). Kegiatan penutup, peneliti memberitahu ada soal untuk tugas dan diskusi yang ada di schoology dan meminta siswa untuk mengirim penyelesaian tugas ke schoology (penugasan). Sebelum salam, peneliti menghitung skor dari masing-masing kelompok dan memberi penghargaan pada kelompok dengan skor tertinggi (rayakan).

Pertemuan 2 memberikan latihan soal dan tes 1 . Kegiatan pendahuluan peneliti menyampaikan review tugas yang telah dikirim siswa. Setelah waktu latihan soal selesai siswa diminta untuk duduk tidak berkelompok dan diadakan tes. Setelah siswa duduk di tempat duduk masingmasing, peneliti membagi soal tes. Setelah tes selesai, peneliti memberitahu ada soal untuk tugas dan diskusi dan meminta siswa untuk mengirim penyelesaian tugas ke schoology. Tes siklus 1 dikoreksi berdasarkan kunci dan pedoman penskoran dan diperoleh data hasil belajar dengan rata-rata 71,71. Diperoleh data hasil belajar siswa yang tuntas ada 7 atau mencapai $23 \%$.

Terdapat 21 siswa mengumpulkan tugas 1 dengan tepat waktu, 8 siswa terlambat, dan 2 siswa tidak mengumpulkan atau siswa yang mengumpulkan tugas 1 ada 94\% dengan keterlambatan 26\%. Terdapat 27 siswa mengumpulkan tugas 2 dengan tepat waktu dan 4 siswa tidak mengumpulkan atau siswa yang mengumpulkan tugas 2 ada $87 \%$. Siswa yang memberi tanggapan pada diskusi 1 hanya ada 4 siswa atau hanya $13 \%$. Keberanian bertanya dan/atau memberi tanggapan pada diskusi 2 hanya ada 5 siswa atau hanya 16\%. Karakter mandiri dari schoology dan kuesioner dapat dilihat pada Tabel 3 dan Tabel 4.

Berdasarkan pengamatan yang ada di schoology selama melakukan tindakan sebanyak dua kali pertemuan masih banyak sekali kekurangan yang terjadi. Kekurangan tersebut adalah peneliti agak terlambat memantau di schoology. 
Tabel 3. Rekapitulasi Aktivitas pada Schoology Siklus 1

\begin{tabular}{llccc}
\hline No & \multicolumn{1}{c}{ Aktivitas Siswa } & Pertemuan 1 & Pertemuan 2 & Kategori \\
\hline 1 & Aktivitas mengumpulkan tugas & $94 \%$ & $87 \%$ & Sangat Baik \\
\hline 2 & $\begin{array}{l}\text { Keberanian bertanya dan/atau } \\
\text { memberi tanggapan }\end{array}$ & $13 \%$ & $16 \%$ & Kurang (15\%) \\
\hline
\end{tabular}

Tabel 4. Rekapitulasi Karakter Mandiri Siklus 1

\begin{tabular}{lll}
\hline No & \multicolumn{1}{c}{ Indikator } & Persentase \\
\hline 1 & ketidaktergantungan terhadap orang lain & $69 \%$ \\
\hline 2 & memiliki kepercayaan diri & $71 \%$ \\
\hline 3 & berperilaku disiplin & $70 \%$ \\
\hline 4 & memiliki rasa tanggungjawab; & $65 \%$ \\
\hline 5 & berperilaku berdasarkan inisiatif sendiri & $71 \%$ \\
\hline 6 & melakukan kontrol diri & $72 \%$ \\
\hline & Rata-rata & $70 \%$ \\
\hline
\end{tabular}

Kekurangan siswa yang terjadi adalah masih sedikit siswa yang aktif di discussion dan belum semua siswa mengirim tugas.

Tahap perencanaan yang dilakukan pada siklus 2 adalah persiapan kegiatan pembelajaran dengan refleksi pada siklus 1 . Peneliti mempersiapkan instrumen penelitian yang terdiri dari perangkat pembelajaran dan instrumen pengumpul data. Jenis perangkat pembelajaran dan pengumpul data sama dengan siklus 1 .

Siklus 2 terdiri dari pertemuan 3 dan 4 sekaligus ulangan harian 2. Kegiatan pendahuluan pada pertemuan 3 adalah mengucapkan salam, mengecek kehadiran siswa, mereview pembelajaran sebelumnya, meminta siswa untuk menyanyi sebuah lagu, dan menyampaikan kompetensi dasar dan tujuan pembelajaran dengan materi rotasi dan dilatasi. Kegiatan inti yang dilakukan adalah mengingatkan kembali permainan memutar buku di atas jari telunjuk (menumbuhkan), meminta dua siswa maju untuk memainkan permainan tersebut (mengalami), mempersilakan siswa untuk bertanya, dan menanggapi pertanyaan. Setelah kegiatan memutar buku selesai, meminta salah satu siswa maju untuk praktik menarik karet gelang (mengalami). Selanjutnya meminta siswa duduk berdasarkan kelompok (berkelompok), dan membagi LKS 2 serta memusatkan perhatian kelompok. Peneliti selanjutnya meminta siswa untuk menyelesaikan masalah yang ada dalam LKS 2 dan membuat mind map (menamai). Kegiatan selanjutnya meminta kelompok untuk maju presentasi hasil diskusi sesuai hasil undian dengan menggunakan mind map yang ditayangkan melalui LCD (mendemonstrasikan). Foto kegiatan ini dapat dilihat pada Gambar 3 berikut.

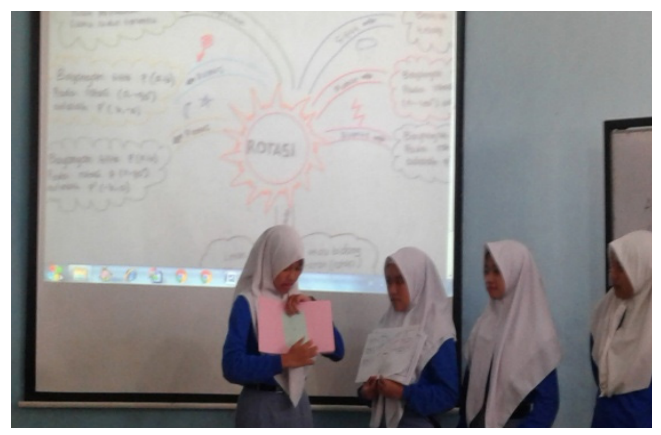

Gambar 3. Kegiatan Mendemonstrasikan Hasil

Selanjutnya peneliti memberi kuis (mengulangi). Kegiatan penutup, peneliti memberitahu ada soal untuk tugas dan diskusi dan meminta siswa untuk mengirim penyelesaian tugas ke schoology (penugasan). Selanjutnya peneliti menyampaikan tanggapan pembelajaran yang telah dilakukan, memberitahu untuk pertemuan berikutnya latihan soal dan tes 2 , menghitung skor pada masing-masing kelompok, memberi penghargaan (rayakan) dan menyampaikan salam penutup. 
Pertemuan 4 memberikan latihan soal dan tes 2 . Kegiatan pendahuluan peneliti menyampaikan review tugas yang telah dikirim siswa. Setelah waktu latihan soal selesai siswa diminta untuk duduk tidak berkelompok dan diadakan tes. Setelah siswa duduk di tempat duduk masingmasing, peneliti membagi soal tes. Setelah tes selesai, peneliti memberitahu ada soal untuk tugas dan diskusi dan meminta siswa untuk mengirim penyelesaian tugas ke schoology. Tes siklus 2 dikoreksi berdasarkan kunci dan pedoman penskoran dan diperoleh data hasil belajar dengan rata-rata 79,23. Diperoleh data hasil belajar siswa yang tuntas ada 22 atau mencapai $71 \%$.

Pengumpulan tugas 3 , ada 13 siswa mengumpulkan tugas dengan tepat waktu, 16 siswa terlambat, dan 2 siswa tidak mengumpulkan atau siswa yang mengumpulkan tugas 3 ada 94\% dengan keterlambatan $52 \%$. Pengumpulan tugas 4 , ada 15 siswa mengumpulkan tugas dengan tepat waktu, 13 siswa terlambat dan 3 siswa tidak mengumpulkan atau siswa yang mengumpulkan tugas 4 ada $87 \%$ dengan keterlambatan $42 \%$. Siswa yang memberi tanggapan pada diskusi 3 hanya ada 2 siswa atau hanya $6 \%$. Untuk keberanian bertanya dan/atau memberi tanggapan pada diskusi 4 hanya ada 3 siswa yang beraktivitas atau hanya $10 \%$. Karakter mandiri dari schoology dan kuesioner dapat dilihat pada Tabel 5 dan Tabel 6. Berdasarkan data yang ada di schoology selama melakukan tindakan sebanyak dua kali pertemuan masih banyak sekali kekurangan yang terjadi. Kekurangan tersebut adalah peneliti kurang memberi sanksi pada siswa yang terlambat mengumpulkan tugas dan kurang memaksa siswa untuk terlibat dalam diskusi.

Tabel 5. Rekapitulasi Aktivitas pada Schoology Siklus 2

\begin{tabular}{llccc}
\hline No & \multicolumn{1}{c}{ Aktivitas Siswa } & Pertemuan 1 & Pertemuan 2 & Kategori \\
\hline 1 & Aktivitas mengumpulkan tugas & $94 \%$ & $87 \%$ & Sangat Baik \\
\hline 2 & $\begin{array}{l}\text { Keberanian bertanya dan/atau } \\
\text { memberi tanggapan }\end{array}$ & $13 \%$ & $16 \%$ & Kurang (15\%) \\
\hline
\end{tabular}

Tabel 6. Rekapitulasi Karakter Mandiri Siklus 2

\begin{tabular}{lll}
\hline No & \multicolumn{1}{c}{ Indikator } & Persentase \\
\hline 1 & ketidaktergantungan terhadap orang lain & $74 \%$ \\
\hline 2 & memiliki kepercayaan diri & $77 \%$ \\
\hline 3 & berperilaku disiplin & $78 \%$ \\
\hline 4 & memiliki rasa tanggungjawab; & $77 \%$ \\
\hline 5 & berperilaku berdasarkan inisiatif sendiri & $78 \%$ \\
\hline 6 & melakukan kontrol diri & $75 \%$ \\
\hline & Rata-rata & $77 \%$ \\
\hline
\end{tabular}

Tabel 7. Rekapitulasi Data Hasil Belajar

\begin{tabular}{llll}
\hline \multicolumn{1}{c}{ Hasil belajar } & \multicolumn{1}{c}{ Kondisi Awal } & Siklus 1 & Siklus 2 \\
\hline Nilai terendah & 31 & 56 & 63 \\
\hline Nilai tertinggi & 97 & 88 & 94 \\
\hline Rata-rata kelas & 58,48 & 71,71 & 79,23 \\
\hline Siswa yang tuntas & 6 & 7 & 22 \\
\hline Ketuntasan belajar & $19 \%$ & $23 \%$ & $71 \%$ \\
\hline
\end{tabular}


Tabel 8. Rekapitulasi Aktivitas pada Schoology

\begin{tabular}{llll}
\hline \multicolumn{1}{c}{ Aktivitas Siswa } & \multicolumn{1}{c}{ Kondisi Awal } & \multicolumn{1}{c}{ Siklus 1 } & \multicolumn{1}{c}{ Siklus 2 } \\
\hline Aktivitas mengumpulkan tugas & Cukup & Sangat Baik & Sangat Baik \\
\hline $\begin{array}{l}\text { Keberanian bertanya dan/atau memberi } \\
\text { tanggapan }\end{array}$ & Baik (76\%) & $\begin{array}{l}\text { Kurang } \\
(15 \%)\end{array}$ & Kurang (8\%) \\
\hline
\end{tabular}

Tabel 9. Rekapitulasi Karakter Mandiri Siswa

\begin{tabular}{lllll}
\hline \multirow{2}{*}{ No } & \multirow{2}{*}{ Indikator } & \multicolumn{3}{c}{ Persentase } \\
\cline { 3 - 5 } & & Kondisi awal & Siklus 1 & Siklus 2 \\
\hline 1 & ketidaktergantungan terhadap orang lain & $64 \%$ & $69 \%$ & $74 \%$ \\
\hline 2 & memiliki kepercayaan diri & $67 \%$ & $71 \%$ & $77 \%$ \\
\hline 3 & berperilaku disiplin & $67 \%$ & $70 \%$ & $78 \%$ \\
\hline 4 & memiliki rasa tanggungjawab; & $62 \%$ & $65 \%$ & $77 \%$ \\
\hline 5 & berperilaku berdasarkan inisiatif sendiri & $67 \%$ & $71 \%$ & $78 \%$ \\
\hline 6 & melakukan kontrol diri & $69 \%$ & $72 \%$ & $75 \%$ \\
\hline & Rata-rata & $66 \%$ & $70 \%$ & $77 \%$ \\
\hline
\end{tabular}

\section{Pembahasan}

Hasil belajar dalam penelitian ini terdiri dari tiga data, yaitu data kondisi awal yang diperoleh dari ulangan harian materi persamaan lingkaran yang diberikan sebelum penelitian, data siklus 1 yang diperoleh dari ulangan harian berkarakteristik literasi matematika materi translasi dan refleksi, dan data siklus 2 yang diperoleh dari ulangan harian berkarakteristik literasi matematika materi rotasi dan dilatasi. Secara ringkas dapat dilihat pada Tabel 7.

Dari tabel di atas tampak bahwa dari hasil belajar kondisi awal terhadap siklus 1 rata-rata kelas mengalami peningkatan sebesar 13,23\% dan untuk siswa yang tuntas mengalami kenaikan sebesar 4\%. Hasil belajar kondisi awal terhadap siklus 2 rata-rata kelas mengalami peningkatan sebesar $20,75 \%$ dan untuk siswa yang tuntas mengalami peningkatan juga yaitu sebesar $52 \%$. Hasil belajar siklus 1 terhadap siklus 2 rata-rata kelas mengalami peningkatan sebesar $7,52 \%$ dan untuk siswa yang tuntas mengalami peningkatan juga yaitu sebesar $48 \%$.

Secara individual, dari kondisi awal terhadap siklus 2 bisa dikatakan berhasil karena siswa yang mendapat nilai minimal 77 mengalami kenaikan lebih dari 10\%. Dari siklus 1 terhadap siklus 2 juga secara individual dikatakan berhasil karena juga mengalami kenaikan lebih dari $10 \%$ untuk siswa yang tuntas. Secara klasikal belum berhasil karena ketuntasan belajar masih di bawah $75 \%$.

Karakter mandiri pada schoology dalam penelitian ini dilihat dari komponen mengumpulkan tugas dan keberanian bertanya dan/atau memberi tanggapan. Secara ringkas dapat dilihat pada Tabel 8 .

Dari tabel tampak bahwa komponen mengumpulkan tugas mengalami kenaikan dari kondisi awal terhadap siklus 1 maupun siklus 2. Komponen keberanian bertanya dan/atau memberi tanggapan mengalami penurunan, baik dari kondisi awal terhadap siklus 1, kondisi awal terhadap siklus 2, maupun siklus 1 terhadap siklus 2. Hal ini disebabkan karena materi, jenis soal, maupun medianya berbeda. Komponen keberanian bertanya dan/ atau memberi tanggapan pada kondisi awal merupakan aktivitas langsung tetapi pada penelitian ini menggunakan bantuan media dimana siswa tidak berhadapan langsung dengan guru. Hal lain yang menjadi kendala karena siswa tidak berminat. Siswa lebih berminat melihat film anime secara online dari pada melihat materi pelajaran secara online. Siswa yang aktif diskusi adalah siswa dengan kemampuan literasi matematika tinggi.

Karakter mandiri dengan 6 indikator mengalami 
kenaikan dari kondisi awal, siklus1, dan siklus 2. Rekapitulasi selengkapnya dapat dilihat pada Tabel 9.

Kenaikan dari kondisi awal terhadap siklus 1 belum mencapai $10 \%$. Kenaikan dari kondisi awal terhadap siklus 2 sudah mencapai $10 \%$. Kenaikan dari kondisi 1 terhadap kondisi 2 belum mencapai $10 \%$. Sesuai dengan indikator keberhasilan maka yang memenuhi adalah kenaikan dari kondisi awal terhadap siklus 2 . Ini artinya perubahan karakter sesuai indikator keberhasilan memerlukan waktu yang lama.

Kenaikan karakter mandiri siswa juga terlihat dari pengumpulan tugas pada schoology yang berkategori sangat bagus. Karakter mandiri siswa juga terlihat dari diskusi pada schoology namun berkategori kurang. Ini artinya antara kuesioner yang diisi siswa dan aktivitas siswa tidak sesuai. Wawancara siswa mengatakan lebih suka bertanya dan memberi tanggapan pada teman sendiri bukan pada guru meskipun melalui schoology. Hasil belajar siswa tinggi mempunyai karakter mandiri juga tinggi. Siswa dengan hasil belajar sedang mempunyai karakter mandiri juga sedang. Siswa dengan hasil belajar rendah mempunyai karakter mandiri rendah.

Berdasarkan hasil penelitian dan pembahasan, maka dapat dikatakan bahwa penelitian ini sudah dapat meningkatkan kemampuan literasi matematika dan karakter mandiri siswa. Dengan demikian hipotesis tindakan tercapai yaitu dengan menggunakan pembelajaran kumima berbantuan schoology dapat meningkatkan kemampuan literasi matematika dan karakter mandiri bagi siswa kelas XI IPS 2 SMA Negeri 1 Rembang tahun pelajaran 2016/2017.

\section{Kesimpulan dan Saran}

Hasil penelitian dan pembahasan diperoleh ketercapaian KKM sebelum tindakan sebanyak 8 siswa sedangkan setelah tindakan pada siklus 1 sebanyak 7 siswa, pada siklus 2 sebanyak 22 siswa. Ini menunjukkan bahwa ketercapaian KKM setelah tindakan memberikan peningkatan terhadap kemampuan literasi matematika siswa kelas XI IPS 2 SMA Negeri 1 Rembang. Karakter mandiri siswa juga mengalami kenaikan terutama dari kondisi awal terhadap siklus 2. Dengan demikian disimpulkan bahwa dengan menggunakan pembelajaran kumima berbantuan schoology dapat meningkatkan kemampuan literasi matematika dan karakter mandiri bagi siswa kelas XI IPS 2 SMA Negeri 1 Rembang tahun pelajaran 2016/2017.

Hasil penelitian ini dapat dijadikan salah satu referensi dalam pembelajaran. Dalam pembelajaran kumima, guru harus menghadirkan suasana yang nyaman dalam diri siswa tidak ada rasa takut yaitu dengan menghadirkan nyanyian di suasana pembelajaran. Guru harus memperbanyak soal yang berkaitan dengan literasi matematika sesuai materi pembelajaran. Dalam penggunaan schoology, guru harus memantau aktivitas pada schoology setiap ada tugas. Pemantauan dilanjutkan dengan memberi tindak lanjut terhadap aktivitas tersebut seperti memberi penilaian dan komentar. Guru yang sedang tugas luar sekolah dapat memanfaatkan schoology sebagai salah satu alternatif pembelajaran jarak jauh dengan mempersiapkan terlebih dahulu materi dan tugas yang harus dikerjakan siswa dan semua siswa terjangkau oleh internet dan sarana lainnya.

\section{Daftar Rujukan}

Adodo. S. O. (2013). "Effect of Mind-Mapping as a Self-Regulated Learning Strategy on Students' Achievement in Basic Science and Technology." Mediterranean Journal of Social Sciences. 4(6): 163 - 172.

Amiroh. (2013). "Antar Moodle, Edmodo dan Schoology.” http://amiroh.web.id/antaramoodle-edmodo-dan-schoology/

DePorter, B. \& Hernacki, M. (2009). Quantum Learning Membiasakan Belajar Nyaman dan Menyenangkan. Terjemahan Alwiyah Abdurrahman. Bandung: Kaifa.

Faelasofi, R., Arnidha, Y., dan Istiani, A. (2015). "Metode Pembelajaran Mind Mapping untuk Meningkatkan Kemampuan Komunikasi Matematik Siswa dalam Pemecahan Masalah Matematika." Jurnal e-DuMath. 1(2): 122 - 136.

Kemendikbud. (2014). Permendikbud Republik Indonesia nomor 59 tahun 2014 tentang 
Kurikulum 2013 Sekolah Menengah Atas/ Madrasah Aliyah Lampiran I.

Murtiyasa, B. (2015). "Tantangan Pembelajaran Matematika Era Global." Prosiding Seminar Nasional Maematika dan Pendidikan Matematika UMS. Hal 28 47.

OECD. (2016). PISA 2015 Result in Focus. https://www.oecd.org/pisa/pisa-2015results-in-fo.. (Diunduh 20 Desember 2016)

Pulungan, D.A. (2014). "Pengembangan Instrumen Tes Literasi Matematika Model PISA." Journal of Education Research and Evaluation. 3(2) : $74-78$.

Wardono \& Kurniasih, A.W. (2015). "Peningkatan Literasi Matematika Mahasiswa Melalui Pembelajaran Inovatif Realistik E-learning Edmodo Bermuatan Karakter Cerdas Kreatif Mandiri.” Jurnal matematika Kreatif-Inovatif (Kreano). 6(1): $93-100$. 